\title{
ANALISIS PROKSIMAT, SENYAWA FENOLIK, SIFAT ANTIOKSIDAN DAN ANTIBAKTERI KULIT BUAH Lepisanthes alata
}

\author{
[Proximate Analysis, Phenolic Content, Antioxidative and Antibacterial Activity \\ of Lepisanthes alata Fruit Skin]
}

\section{Anton Rahmadi ${ }^{*}$, Yuliadini Puspita, Desy Nursayekti, Ira Sintia Sinaga, Rica Oktalina, Herry Setiawan, dan Wiwit Murdianto}

Jurusan Teknologi Hasil Pertanian, Fakultas Pertanian, Universitas Mulawarman, Samarinda

Diterima 27 Mei 2016 / Disetujui 13 Desember 2016

\begin{abstract}
Bengalun (Lepisanthes alata) is a rare and under-reported fruit native from the forests of Borneo. This fruit is non-seasonal with a thick skin and crimson color, therefore shows potential to be used as raw material for herbal tea. This research was conducted in three phases, namely: (1) to report proximate portions of seed, flesh and skin of the fruit, (2) to find the best combination of time and temperature of fruit skin drying, and (3) to explore the potential antioxidant and antibacterial capacity of fruit skin extracts produced in step (2). Proximate analysis carried out following oven-drying $\left(60^{\circ} \mathrm{C}, 12\right.$ hours) and sun-drying (8 hours). Combination of oven temperature $\left(40,50,60^{\circ} \mathrm{C}\right)$ and time $(8,10,12$ hours) was given to find the best drying treatment in terms of vitamin $C$, total phenols and anthocyanins. Anthocyanins levels approached qualitatively by red color absorbance $(\lambda=545 \mathrm{~nm})$. The antioxidative capacity was approached with DPPH assay. Inhibition zones were measured against Staphylococcus aureus and Escherichia coli. Best drying treatment was at $60^{\circ} \mathrm{C}$ for 8 hours with moisture content of $6.73 \pm 0.18 \%$, vitamin $\mathrm{C}$ of $76.9 \pm 3$ $\mathrm{mg} / 100 \mathrm{~g}$, total phenols of $1112 \pm 8 \mathrm{mg} \mathrm{GAE} / \mathrm{kg}$, and red color absorbance of $0.259 \pm 0.060$. The average $I C_{50}$ antioxidant activity for the fruit skin extracts was $252.83 \pm 1.38 \mathrm{ppm}$. Ethanolic extract produced inhibition zones from $10.76 \%(1.0 \mathrm{mg}$ extract/50 $\mu \mathrm{L}$ ) to $22.77 \%$ (1.5 mg extract/50 $\mu \mathrm{L})$, when compared to the positive control. Aquadest extract produced inhibition zones ranging from $7.99 \%(0.5 \mathrm{mg} / 50 \mu \mathrm{L})$ to $11.00 \%(1.5 \mathrm{mg} / 50 \mu \mathrm{L})$. N-hexane extracts showed no antibacterial activity.
\end{abstract}

Keywords: antibacterial properties, antioxidant, Lepisanthes alata, proximate analysis, vitamin C

\begin{abstract}
ABSTRAK
Bengalun (Lepisanthes alata) merupakan buah eksotis langka dari Kalimantan. Buah ini tergolong dalam keluarga Sapindaceae yang merupakan buah non musiman dengan kulit tebal dan berwarna merah tua serta dapat dimanfaatkan sebagai bahan baku teh herbal. Penelitian ini dilakukan dalam tiga tahapan, yaitu: (1) melaporkan profil proksimat bagian-bagian buah, (2) menemukan kombinasi terbaik dari waktu dan suhu pengeringan bahan baku herbal dari kulit buah, serta (3) mengeksplorasi potensi antioksidan dan antibakteri ekstrak kulit buah hasil pengeringan terbaik. Analisis proksimat dilakukan terhadap bagianbagian buah yang dikering oven $\left(60^{\circ} \mathrm{C}, 12 \mathrm{jam}\right)$ dan dikering matahari (8 jam). Kombinasi suhu oven (40, $\left.50,60^{\circ} \mathrm{C}\right)$ dan waktu $(8,10,12$ jam) diberikan untuk mencari bahan baku teh herbal terbaik dilihat dari vitamin C, total fenol, dan antosianin. Kadar antosianin didekati secara kualitatif dengan pengukuran absorbansi warna merah $(\lambda=545 \mathrm{~nm})$. Kandungan antioksidan didekati dengan metode DPPH. Zona inhibisi ekstrak diukur terhadap Staphylococcus aureus dan Escherichia coli. Kulit buah terbaik dihasilkan dari pengeringan $60^{\circ} \mathrm{C}$ selama 8 jam dengan kadar air $6,73 \pm 0,18 \%$, vitamin $\mathrm{C} 76,9 \pm 3 \mathrm{mg} / 100 \mathrm{~g}$, total fenolik $1112 \pm 8 \mathrm{mg} \mathrm{GAE} / \mathrm{kg}$, dan absorbansi warna merah $0,259 \pm 0,060$. Rata-rata $\mathrm{IC}_{50}$ aktivitas antioksidan terhadap DPPH untuk ekstrak kulit buah bengalun hasil pengeringan terbaik adalah $252,83 \pm 1,38 \mathrm{ppm}$. Ekstrak etanolik dari kulit buah menghasilkan zona inhibisi dari 10,76\% (1,0 mg ekstrak/50 $\mu \mathrm{L})$ menjadi $22,77 \%$ (1,5 mg ekstrak/50 $\mu \mathrm{L})$, jika dibandingkan dengan kontrol positif. Ekstrak air suling kulit buah menghasilkan zona inhibisi mulai dari $7,99 \%(0,5 \mathrm{mg} / 50 \mu \mathrm{L})$ hingga $11,00 \%(1,5 \mathrm{mg} / 50 \mu \mathrm{L})$, jika dibandingkan dengan kontrol positif. Ekstrak n-heksana tidak menunjukkan aktivitas antibakteri terhadap S.aureus dan E.coli.
\end{abstract}

Kata kunci: antibakteri, antioksidan, Lepisanthes alata, proksimat, vitamin C

*Penulis Korespondensi:

E-mail: arahmadi@unmul.ac.id 


\section{PENDAHULUAN}

Bengalun merupakan tanaman khas tropis dari keluaga Sapindaceae yang tumbuh di sepanjang dataran rendah sungai dan hutan tropis hingga ketinggian $500 \mathrm{~m}$ (Lim, 2013). Bengalun dikenal sebagai buah rambai merah, Ngalun, atau Keyem di Kalimantan (Setyowati et al., 2005), atau Belimbing Cina, Ceri Trengganu, dan Pohon Johor di Semenanjung Malaysia (Yeo et al., 2013; Mirfat dan Umi, 2014). Buah bengalun termasuk langka ditemukan dan tidak diperdagangkan, sekalipun tanamannya masih dapat ditemukan di hutan-hutan di wilayah Kalimantan dan Semenanjung Malaysia (Chotimah et al., 2013). Dikarenakan utilisasi yang rendah dan kelangkaannya, publikasi tentang bengalun masih sangat terbatas.

Buah dikonsumsi langsung dan daun muda bengalun dapat digunakan sebagai sayuran. Bengalun diketahui sebagai sumber vitamin $C(16 \mathrm{mg} / 100$ g) dan serat $(9,5 \%$ dietary fiber) (Lim, 2013). Keunggulan buah bengalun adalah jumlah buah yang relatif banyak dengan jarak panen dua hingga tiga bulan. Kulit buah bengalun berwarna merah pekat dan cukup tebal. Rasa kulit buah adalah asam, sedikit manis, dan memiliki after taste sepat yang cukup kuat. Dilihat dari deskripsinya, kulit buah bengalun dapat menjadi kandidat alternatif teh herbal kaya pigmen merah (kelompok antosanin) khas dari Kalimantan (Gambar 1). Secara tradisional, kulit buah bengalun dapat dikonsumsi sebagai obat dalam bentuk ramuan menyerupai teh herbal.

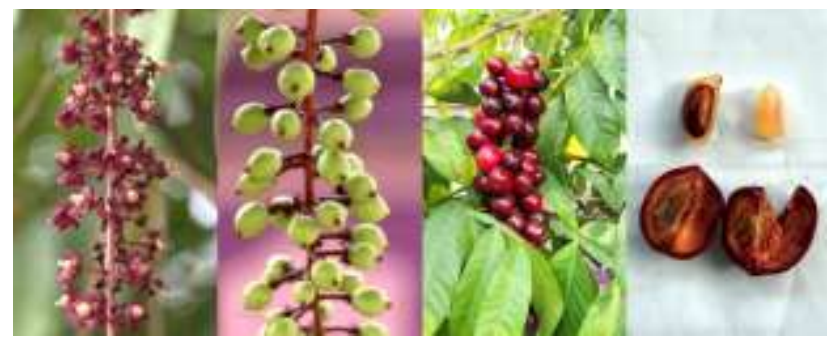

Gambar 1. llustrasi buah bengalun (Lepisanthes alata)

Teh herbal merupakan sebutan bagi minuman yang menyerupai teh dari $C$. sinensis. Teh berkembang dengan munculnya produk-produk seperti teh rambut jagung (Harun et al., 2011), teh bunga rosella (Mun'im et al., 2008), teh bunga lotus (Kusumaningrum et al., 2013) serta teh yang terbuat dari kulit buah seperti teh kulit manggis (Simanjuntak, 2014) dan teh kulit buah naga (Purnomo, 2013).

Berdasarkan hasil skrining fitokimia, ekstrak etanol keluarga Sapindaceae yang lain yaitu kulit buah langsat, terdapat metabolit sekunder berupa fenol, triterpenoid, tanin, saponin, flavonoid dan alkaloid. Senyawa-senyawa tersebut memiliki aktivitas antibakteri dengan berbagai mekanisme kerja (Sepdahlia, 2013). Analisis proksimat awal daging buah bengalun telah dilakukan oleh Mirfat dan Umi (2014). Proksimat kandungan bagian-bagian lain dalam buah bengalun belum pernah dilaporkan dalam publikasi, sehingga profil proksimat dari biji, daging, dan kulit buah bengalun yang dikeringkan dengan metode oven dan matahari dilakukan di tahap awal penelitian ini.

Selanjutnya, untuk menghasilkan teh herbal, kulit buah bengalun perlu untuk dikeringkan. Pengeringan merupakan salah satu faktor penentu komposisi bahan, utamanya kandungan penyusun aktivitas antioksidan dari golongan fenol, tanin, dan antosianin. Tahap kedua penelitian ini adalah untuk mengetahui pengaruh suhu, waktu, serta kombinasi suhu dan waktu pengeringan terhadap kadar air, kandungan vitamin $\mathrm{C}$, total fenol, dan antosianin. Karena standar yang tidak tersedia, kadar antosianin secara kualitatif didekati dengan pengukuran absorbansi warna merah $(\lambda=545 \mathrm{~nm})$.

Tahap ketiga adalah menguji potensi antioksidan dan antibakteri produk dilihat dari kombinasi suhu dan waktu pengeringan terbaik. Potensi antioksidan didekati dengan reduksi senyawa 1,1Diphenyl-2-picryl-hydrazyl (DPPH). Daya hambat ekstrak kulit buah bengalun dengan pelarut etanol 95\%, n-heksana, dan akuades diujikan terhadap pertumbuhan bakteri Gram (+) yang diwakili Staphylococus aureus dan bakteri Gram (-) yang diwakili Escherichia coli.

\section{BAHAN DAN METODE}

\section{Bahan}

Bahan yang digunakan dalam penelitian ini adalah kulit buah bengalun yang diambil dari kebun koleksi plasma nutfah di Samarinda, Kalimantan Timur. Suspensi bakteri uji Staphylococus aureus dan Escherichia coli diperoleh dari kultur koleksi FMIPA Universitas Mulawarman, Samarinda, Kalimantan Timur.

\section{Tahapan penelitian}

Penelitian ini dilakukan dalam tiga tahapan, yaitu melaporkan profil proksimat bagian-bagian buah bengalun. Analisis proksimat digunakan di awal untuk membandingkan kulit, daging, dan biji buah bengalun yang dikeringkan oven pada suhu $60^{\circ} \mathrm{C}$ selama 12 jam dan matahari selama \pm 8 jam. Uji T jamak dilakukan untuk membandingkan hasil pengeringan oven dan matahari dengan perangkat lunak GraphPad Prism versi 6. Hasil ini digunakan sebagai data awal dari pemanfaatan kulit buah bengalun. 
Tahap kedua adalah menentukan kombinasi suhu dan waktu terbaik pengeringan kulit buah bengalun sebagai bahan baku teh herbal. Rancangan Acak Lengkap (RAL) untuk proses pengeringan kulit buah bengalun dilakukan dengan dua faktor dan tiga ulangan. Faktor pertama adalah suhu pengeringan pada tiga taraf yaitu 40,50 , dan $60^{\circ} \mathrm{C}$. Faktor kedua adalah lama pengeringan pada tiga taraf yaitu: 8, 10, dan 12 jam. Pengamatan meliputi kadar air, kadar abu, vitamin C, total polifenol, dan absorbansi warna. Data yang diperoleh dianalisis sidik ragam (ANOVA) dengan perangkat lunak GraphPad Prism versi 6. Jika terdapat pengaruh yang berbeda nyata pada taraf a $5 \%$, maka dilakukan uji lanjut perbandingan jamak.

Tahap ketiga adalah analisis potensi antioksidan dengan metode DPPH dan potensi antibakteri kulit buah bengalun. Analisis antibakteri menggunakan RAL faktor tunggal yaitu konsentrasi ekstrak dengan dua kali ulangan untuk masing-masing ekstrak dengan pelarut etanol, akuades, dan nheksana. Konsentrasi yang digunakan adalah akuades (kontrol negatif), 0,5; 1; dan 1,5 mg ekstrak. Data yang diperoleh dianalisis dengan menghitung rerata zona hambatan dari ketiga ekstrak terhadap pertumbuhan bakteri.

\section{Proses pengolahan teh kulit buah bengalun}

Buah bengalun dibersihkan dengan air mengalir untuk menghilangkan kotoran-kotoran yang menempel pada kulit buah tersebut. Kemudian dilakukan pengupasan yang menghasilkan daging buah, biji buah, dan kulit buah bengalun. Kulit buah bengalun ditiriskan kemudian dipotong-potong menjadi ukuran $\pm 2-3 \mathrm{~cm}$. Diambil sebanyak $200 \mathrm{~g}$ kulit buah bengalun dan dilakukan pengeringan pada suhu 40, 50, dan $60^{\circ} \mathrm{C}$ selama 8,10 , dan 12 jam. Dilakukan uji untuk mengetahui kadar air, kadar abu, kadar vitamin $\mathrm{C}$, total fenolik, dan absorbansi warna.

\section{Uji proksimat dan vitamin C}

Analisis kadar air, kadar abu, total padatan terlarut (TPT), kadar protein, kadar lemak, dan vitamin $\mathrm{C}$ dikerjakan dengan menggunakan metode AOAC (1984) yang disitasi oleh Sudarmaji et al. (2007).

\section{Uji kadar antosianin}

Analisis kadar antosianin secara kualitatif dilakukan dengan pendekatan pengukuran absorbansi warna merah pada panjang gelombang $545 \mathrm{~nm}$. Sampel ditimbang sebanyak $5 \mathrm{mg}$ dilarutkan dalam tabung dalam $2 \mathrm{~mL}$ etanol $95 \%$ dalam gelas ukur. Selanjutnya, sampel diukur pada panjang gelombang $545 \mathrm{~nm}$ (Genesys 20, Thermo Fisher).

\section{Uji total fenolik (metode Chinedum et al., 2015)}

Analisis fenol ini dilakukan secara spektrofotometri dengan menggunakan metode Folin-Ciocalteu dan sebagai pembanding digunakan asam galat (Sigma-Aldrich, USA). Kandungan total fenolat dalam kulit buah bengalun dinyatakan dalam gallic acid equivalent (GAE). Sampel ditimbang sebanyak $5 \mathrm{mg}$ dilarutkan dalam tabung dalam $2 \mathrm{~mL}$ etanol $95 \%$. Selanjutnya, ditambahkan $5 \mathrm{~mL}$ aquades dan $0,5 \mathrm{~mL}$ reagen Folin-Ciocalteau (Sigma-Aldrich, USA) $50 \%(v / v)$. Sampel didiamkan selama 5 menit dan ditambahkan larutan $\mathrm{Na}_{2} \mathrm{CO}_{3}$ (Sigma-Aldrich, USA) $5 \%(b / v)$ sampai volume total mencapai 10 $\mathrm{mL}$. kemudian larutan tersebut dihomogenkan dalam ruang gelap selama 1 jam. Setelah homogen, larutan tersebut diukur absorbansinya pada panjang gelombang $752 \mathrm{~nm}$.

\section{Uji aktivitas antioksidan metode DPPH (Shekhar et al., 2014)}

Uji aktivitas antioksidan dilakukan secara spektrofotometri dengan mengukur penghambatan reduksi DPPH (Sigma Aldrich, USA). Sebanyak 1 $\mathrm{mL}$ konsentrasi yang berbeda dari ekstrak ditambahkan ke $1 \mathrm{~mL}$ DPPH $(0,15 \mathrm{mM}$ dalam etanol) dan pada saat yang sama, kontrol yang terdiri atas DPPH $1 \mathrm{~mL}$ dengan $1 \mathrm{~mL}$ etanol disiapkan. Campuran reaksi dicampur dengan baik dengan tangan lalu diinkubasi dalam keadaan gelap pada suhu ruang $\left(30 \pm 2^{\circ} \mathrm{C}\right)$ selama 30 menit. Absorbansi diukur pada panjang gelombang $517 \mathrm{~nm}$, dimana etanol digunakan sebagai blanko. Nilai $I_{50}$ aktivitas antioksidan ditentukan dengan menggunakan regresi linier pada konsentrasi 31,25; 62,5; 125; 250; dan 500 ppm. Pengamatan dilakukan secara duplo dengan dua kali ulangan.

\section{Uji aktivitas antimikroba}

Sebanyak $200 \mathrm{~g}$ sampel bubuk kulit buah bengalun pada kombinasi suhu dan waktu pengeringan terpilih diekstraksi dengan metode maserasi dalam $500 \mathrm{~mL}$ pelarut yang berbeda yaitu etanol 95\%, n-heksana (Merck, USA) dan akuades selama 48 jam pada suhu ruang $\left(30 \pm 2^{\circ} \mathrm{C}\right)$ sambil dilakukan beberapa kali pengadukan. Filtrat kulit buah bengalun dipekatkan dengan oven pada suhu $60^{\circ} \mathrm{C}$ hingga didapatkan ekstrak pekat kulit buah bengalun $( \pm 6$ jam). Uji aktivitas antimikroba dilakukan dengan metode sumur difusi seperti yang dikerjakan oleh Rahmadi et al. (2013).

Bakteri Gram (+) dan bakteri Gram (-) yang digunakan adalah Staphylococus aureus dan Escherichia coli. Sebanyak $1 \mathrm{~mL}$ suspensi $\left(1 \times 10^{4}\right.$ $\mathrm{CFU} / \mathrm{mL}$ ) Staphylococus aureus dan Escherichia coli diinokulasikan ke dalam masing-masing cawan petri yang di dalamnya terdapat 5 buah pencadang steril. Kemudian, medium nutrient agar (NA) (Accumedia, USA) bersuhu hangat $\left( \pm 50^{\circ} \mathrm{C}\right)$ dituangkan ke dalam 
cawan petri sebanyak $\pm 25 \mathrm{~mL}$. Kemudian agar dihomogenkan dan dibiarkan sampai mengeras. Setelah media mengeras, pencadang tersebut dicabut dengan menggunakan pinset steril, sehingga terbentuk lubang sumur pada media. Setiap cawan petri yang memiliki lima lubang sumur yang masingmasing ditambahkan $50 \mu \mathrm{L}$ akuades steril (kontrol negatif), antibakteri tetrasiklin (Kimia Farma) (kontrol positif) $0,5 \mathrm{mg} / 50 \mu \mathrm{L}$, dan ekstrak kulit buah bengalun dari setiap jenis pelarut dengan konsentrasi yang berbeda-beda yaitu: 0,5; 1; dan 1,5 mg. Cawan petri diinkubasikan pada suhu $37^{\circ} \mathrm{C}$ selama 24 jam. Pengamatan dilakukan dengan mengukur diameter areal bening yang terbentuk di sekeliling sumur sebanyak dua kali untuk diambil rata-ratanya. Pengamatan dilakukan secara duplo dengan dua kali ulangan.

\section{HASIL DAN PEMBAHASAN}

\section{Proksimat bagian buah bengalun}

Pembahasan proksimat kulit dan biji buah dari keluarga Sapindaceae masih sangat terbatas. Kulit buah Bengalun memiliki kadar air berkisar antara $15,43 \pm 0,34$ dan $17,16 \pm 0,10 \%$, lemak $2,39 \pm 0,17 \%$, protein antara $4,29 \pm 0,16$ dan $5,30 \pm 0,12 \%$, kadar abu antara $0,10 \pm 0,01$ dan $0,39 \pm 0,06 \%$, dan TPT adalah berkisar 2,03 $\pm 0,05$ oBrix (Tabel 1). Dibandingkan dengan biji dan daging buah, kandungan lemak, protein, dan kadar air kulit buah bengalun lebih tinggi. Hasil proksimat untuk daging buah bengalun tidak jauh berbeda dengan yang disampaikan oleh Mirfat dan Umi (2014).

Biji buah bengalun memiliki kadar air bekisar antara $7,26 \pm 0,18$ dan $8,19 \pm 0,12 \%$, lemak $0,32 \pm$ $0,02 \%$, protein antara $1,27 \pm 0,13$ dan $3,16 \pm 0,15 \%$, kadar abu 0,39 $\pm 0,06 \%$, dan TPT adalah berkisar $1,1 \pm 0,15 \stackrel{\circ}{\circ}$ Brix (Tabel 1). Kecuali kadar protein dan kadar air, tidak ada perbedaan yang signifikan antara hasil analisis proksimat dan TPT antara biji buah bengalun yang dikeringmataharikan dengan yang di oven pada suhu $60^{\circ} \mathrm{C}$. Bila dibandingkan dengan keluarga Sapindaceae yang sama, biji buah

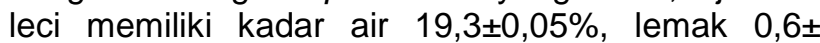
$0,06 \%$, protein antara $3,98 \pm 0,06$ dan $5,4 \pm 0,26 \%$, kadar abu antara $1,53 \pm 0,07$ dan $1,8 \pm 0,16 \%$, serat antara $8,32 \pm 0,32$ dan $9,98 \pm 0,22 \%$, serta total karbohidrat by difference antara 70,88 dan 72,9\% (Luzia dan Jorge, 2011; Wisitsak et al., 2012). Data pada Tabel 2 menginformasikan bahwa semakin tinggi suhu pengeringan, semakin rendah kadar air. Akan tetapi, kadar air cenderung sama untuk waktu pengeringan yang berbeda (Tabel 3). Ini disebabkan waktu pengeringan tercepat sudah cukup untuk mengurangi sebagian besar air yang terkandung di dalam kulit buah bengalun.

\section{Vitamin C kulit buah bengalun}

Vitamin $C$ kulit buah bengalun relatif hampir sama pada kisaran $55,7 \pm 11,5$ hingga $85,6 \pm 2,5$ $\mathrm{mg} / 100 \mathrm{~g}$ (Tabel 4). Kandungan vitamin C dipengaruhi oleh proses dan metode pengeringan. Santos dan Silva (2008) menyatakan bahwa pengeringan akan menyebabkan perubahan konsentrasi vitamin $\mathrm{C}$, dengan retensi terbaik diperoleh pada pengeringan dengan pembekuan (freeze drying). Proses pengeringan matahari yang banyak dilakukan akan memberikan efek penurunan vitamin $C$ sebagai akibat paparan cahaya ultraviolet dan inframerah yang mengoksidasi sebagian vitamin C (Zhou et al., 2016). Vitamin C termasuk komponen yang labil dan menjadi indikator degradasi antioksidan larut air. Vega-Gálvez et al. (2009) menyatakan bahwa penurunan kadar vitamin $\mathrm{C}$ adalah disebabkan degradasi oksidatif yang irreversible. Paparan suhu pengeringan dimulai dari $50^{\circ} \mathrm{C}$ akan mengurangi kadar vitamin C hingga $75 \%$ pada buah blueberry (Lopez et al., 2010). Kinetika penurunan kadar vitamin C pada kombinasi waktu dan suhu pengeringan mengikuti persamaan ordo pertama dengan faktor utama adalah suhu (Marfil et al., 2008).

Tabel 1. Hasil analisis proksimat dan TPT pada berbagai bagian buah bengalun dengan metode pengeringan oven dan matahari

\begin{tabular}{|c|c|c|c|c|c|c|}
\hline Bagian Buah & Metode Pengeringan & TPT ( ${ }^{\circ}$ Brix) & Lemak (\%) & Protein (\%) & Air (\%) & Abu (\%) \\
\hline \multirow[t]{2}{*}{ Kulit } & $\begin{array}{c}\text { Oven } \\
\left(60^{\circ} \mathrm{C}, 12 \text { jam }\right)\end{array}$ & $2,03 \pm 0,05$ & $2,39 \pm 0,17$ & $5,30 \pm 0,12^{*}$ & $15,43 \pm 0,34^{\star}$ & $0,10 \pm 0,01$ \\
\hline & $\begin{array}{l}\text { Matahari } \\
( \pm 8 \text { jam })\end{array}$ & $2,00 \pm 0,01$ & $2,28 \pm 0,18$ & $4,29 \pm 0,16$ & $17,16 \pm 0,10$ & $0,39 \pm 0,06$ \\
\hline \multirow[t]{2}{*}{ Biji } & $\begin{array}{c}\text { Oven } \\
\left(60^{\circ} \mathrm{C}, 12 \text { jam }\right)\end{array}$ & $1,10 \pm 0,15$ & $0,33 \pm 0,03$ & $3,16 \pm 0,15^{\star}$ & $7,26 \pm 0,18^{*}$ & $0,38 \pm 0,06$ \\
\hline & $\begin{array}{l}\text { Matahari } \\
( \pm 8 \text { jam })\end{array}$ & $1,00 \pm 0,01$ & $0,32 \pm 0,02$ & $1,27 \pm 0,13$ & $8,19 \pm 0,12$ & $0,39 \pm 0,06$ \\
\hline \multirow[t]{2}{*}{ Daging } & $\begin{array}{c}\text { Oven } \\
\left(60^{\circ} \mathrm{C}, 12 \text { jam }\right)\end{array}$ & $3,00 \pm 0,01$ & $1,33 \pm 0,10$ & $2,29 \pm 0,18$ & $5,85 \pm 0,66$ & $0,51 \pm 0,07$ \\
\hline & $\begin{array}{l}\text { Matahari } \\
( \pm 8 \text { jam })\end{array}$ & $3,00 \pm 0,01$ & $1,20 \pm 0,07$ & $2,28 \pm 0,19$ & $7,24 \pm 0,07$ & $0,46 \pm 0,04$ \\
\hline
\end{tabular}

Keterangan: *Menandakan berbeda nyata dalam uji T perbandingan jamak 
Pada pengukuran vitamin $\mathrm{C}$ kulit buah bengalun, didapatkan hasil bahwa pengeringan pada kombinasi suhu dan waktu dimaksud menghasilkan nilai vitamin $C$ yang tidak berbeda nyata. Ini diduga karena heterogenitas usia panen sampel yang kurang merata. Kadar vitamin $\mathrm{C}$ dalam pengolahan pasca panen dapat dipengaruhi oleh heterogenitas sampel, kadar air, pengelupasan kulit, dan perendaman awal (Marfil et al., 2008).

Tabel 2. Pengaruh suhu pengeringan terhadap kadar air, abu, vitamin C, fenol, dan absorbansi warna pada kulit buah bengalun

\begin{tabular}{lcccc}
\hline $\begin{array}{c}\text { Suhu } \\
\text { Penge- } \\
\text { ringan }\end{array}$ & $\begin{array}{c}\text { K. Air } \\
(\%)\end{array}$ & $\begin{array}{c}\text { Vit. C } \\
(\mathrm{mg} / \\
100 \mathrm{~g})\end{array}$ & $\begin{array}{c}\text { Fenol } \\
(\mathrm{mg} \\
\mathrm{GAE} / \mathrm{Kg})\end{array}$ & $\begin{array}{c}\text { Abs. Warna } \\
(\lambda=545 \mathrm{~nm})\end{array}$ \\
\hline Oven & $7,58 \pm$ & $65,2 \pm$ & $793 \pm$ & $0,164 \pm$ \\
$\left(40^{\circ} \mathrm{C}\right)$ & $0,09^{\mathrm{a}}$ & $11,4^{\mathrm{a}}$ & $65^{\mathrm{a}}$ & $0,073^{\mathrm{a}}$ \\
Oven & $6,91 \pm$ & $80,4 \pm$ & $970 \pm$ & $0,212 \pm$ \\
$\left(50^{\circ} \mathrm{C}\right)$ & $0,37^{\mathrm{ab}}$ & $7,48^{\mathrm{a}}$ & $93^{\mathrm{b}}$ & $0,007^{\mathrm{a}}$ \\
Oven & $6,00 \pm$ & $79,5 \pm$ & $1011 \pm$ & $0,252 \pm$ \\
$\left(60^{\circ} \mathrm{C}\right)$ & $0,63^{\mathrm{b}}$ & $2,6^{\mathrm{a}}$ & $105^{\mathrm{b}}$ & $0,007^{\mathrm{a}}$ \\
Rata- & $6,83 \pm$ & $75 \pm$ & $925 \pm$ & $0,209 \pm$ \\
rata & $0,78^{\mathrm{ab}}$ & $10,1^{\mathrm{a}}$ & $129^{\mathrm{ab}}$ & $0,053^{\mathrm{a}}$ \\
\hline
\end{tabular}

Keterangan: Angka yang sama menandakan tidak berbeda nyata pada taraf $\alpha 5 \%$

Tabel 3. Pengaruh waktu pengeringan terhadap kadar air, abu, vitamin C, fenol, dan absorbansi warna pada kulit buah bengalun

\begin{tabular}{lcccc}
\hline $\begin{array}{c}\text { Waktu } \\
\text { Pengeri- } \\
\text { ngan }\end{array}$ & $\begin{array}{c}\text { K. Air } \\
(\%)\end{array}$ & $\begin{array}{c}\text { Vit. C } \\
(\mathrm{mg} / \\
100 \mathrm{~g})\end{array}$ & $\begin{array}{c}\text { Fenol } \\
(\mathrm{mg} \\
\mathrm{GAE} / \mathrm{Kg})\end{array}$ & $\begin{array}{c}\text { Abs. } \\
\text { Warna } \\
(\lambda=545 \\
\mathrm{nm})\end{array}$ \\
\hline Oven & $7,19 \pm$ & $68,1 \pm$ & $895 \pm$ & $0,183 \pm$ \\
(8 jam) & $0,41^{\mathrm{a}}$ & $11,1^{\mathrm{a}}$ & $181^{\mathrm{a}}$ & $0,092^{\mathrm{a}}$ \\
Oven & $6,65 \pm$ & $75,7 \pm$ & $905 \pm$ & $0,216 \pm$ \\
(10 jam) & $1,03^{\mathrm{a}}$ & $12,2^{\mathrm{a}}$ & $61^{\mathrm{b}}$ & $0,030^{\mathrm{a}}$ \\
Oven & $6,66 \pm$ & $81,2 \pm$ & $974 \pm$ & $0,228 \pm$ \\
(12 jam) & $0,96^{\mathrm{a}}$ & $3^{\mathrm{a}}$ & $124^{\mathrm{a}}$ & $0,015^{\mathrm{a}}$ \\
Rata-rata & $6,83 \pm$ & $75 \pm$ & $925 \pm$ & $0,209^{\mathrm{a}} \pm$ \\
& $0,78^{\mathrm{a}}$ & $10,1^{\mathrm{a}}$ & $129^{\mathrm{ab}}$ & $0,053^{\mathrm{a}}$ \\
\hline
\end{tabular}

Keterangan: Angka yang sama menandakan tidak berbeda nyata pada taraf $\alpha 5 \%$

\section{Antosianin dan polifenol kulit buah bengalun}

Antosianin termasuk dalam komponen pembentuk warna merah dan termasuk dalam kelompok flavonoid. Komponen antosianin digunakan sebagai pewarna alami, dapat diambil dari buah-buahan maupun umbi-umbian, diantaranya kulit manggis, kulit rambutan (Basitah, 2015), dan kunyit (Chinedum et al., 2015). Sebagai bagian dari kelompok tanin tidak terkondensasi, antosianin diharapkan dapat menjadi antioksidan alami yang berperan dalam pencegahan penyakit akibat radikal bebas. Dalam penelitian ini, perubahan warna (pigmen antosianin) diamati pada ekstrak etanolik dari kulit buah bengalun dapat deteksi secara kualitatif pada panjang gelombang $545 \mathrm{~nm}$ (Gokilamani et al., 2013). Ekstrak etanolik bengalun memiliki absorbansi warna $0,081 \pm 0,013$ hingga $0,259 \pm 0,060$ (Tabel 4). Didapatkan bahwa antosianin secara relatif menjadi lebih pekat pada penggunaan oven $60^{\circ} \mathrm{C}$ dibandingkan dengan pengeringan oven suhu 40 dan $50^{\circ} \mathrm{C}$ (Tabel 2). Lama waktu pengeringan pada suhu $40^{\circ} \mathrm{C}$ secara konsisten meningkatkan absorbansi dari ekstrak etanolik kulit buah bengalun (Tabel 4), sekalipun fenomena ini tidak terulang pada suhu 50 dan $60^{\circ} \mathrm{C}$.

Tabel 4. Pengaruh interaksi suhu dan waktu pengeringan terhadap kadar air, abu, vitamin $\mathrm{C}$, fenol, dan absorbansi warna pada kulit buah bengalun

\begin{tabular}{lcccc}
\hline Perlakuan & $\begin{array}{c}\text { K. Air } \\
(\%)\end{array}$ & $\begin{array}{c}\text { Vit. C } \\
(\mathrm{mg} / \\
100 \mathrm{~g})\end{array}$ & $\begin{array}{c}\text { Fenol } \\
(\mathrm{mg} \\
\mathrm{GAE} / \mathrm{Kg})\end{array}$ & $\begin{array}{c}\text { Abs. } \\
\text { Warna } \\
(\lambda=545 \\
\mathrm{nm})\end{array}$ \\
\hline $40^{\circ} \mathrm{C}$, & $7,50 \pm$ & $55,7 \pm$ & $713 \pm$ & $0,081 \pm$ \\
8 jam & $0,33^{\mathrm{c}}$ & $11,5^{\mathrm{a}}$ & $17^{\mathrm{a}}$ & $0,013^{\mathrm{a}}$ \\
10 jam & $7,68 \pm$ & $62 \pm$ & $850 \pm$ & $0,193 \pm$ \\
& $0,32^{\mathrm{c}}$ & $7^{\mathrm{a}}$ & $13^{\mathrm{b}}$ & $0,115^{\mathrm{a}}$ \\
$12 \mathrm{jam}$ & $7,56 \pm$ & $77,9 \pm$ & $816 \pm$ & $0,219 \pm$ \\
& $0,30^{\mathrm{c}}$ & $13,1^{\mathrm{b}}$ & $18^{\mathrm{db}}$ & $0,184^{\mathrm{a}}$ \\
$50^{\circ} \mathrm{C}$, & $7,33 \pm$ & $71,8 \pm$ & $861 \pm$ & $0,210 \pm$ \\
8 jam & $0,10^{\mathrm{c}}$ & $3,6^{\mathrm{a}}$ & $17^{\mathrm{c}}$ & $0,153^{\mathrm{a}}$ \\
10 jam & $6,64 \pm$ & $85,6 \pm$ & $980 \pm$ & 0,206 \\
& $0,34^{\mathrm{b}}$ & $2,5^{\mathrm{b}}$ & $7^{\mathrm{e}}$ & $0,130^{\mathrm{a}}$ \\
12 jam & $6,76 \pm$ & $83,7 \pm$ & $1,068 \pm$ & $0,220 \pm$ \\
& $0,13^{\mathrm{b}}$ & $20,8^{\mathrm{b}}$ & $3^{\dagger}$ & $0,067^{\mathrm{a}}$ \\
$60^{\circ} \mathrm{C}$, & $6,73 \pm$ & $76,9 \pm$ & $1,112 \pm$ & $0,259 \pm$ \\
8 jam & $0,18^{\mathrm{b}}$ & $3^{\mathrm{b}}$ & $8^{\mathrm{g}}$ & $0,060^{\mathrm{a}}$ \\
10 jam & $5,62 \pm$ & $79,4 \pm$ & $883 \pm$ & $0,250 \pm$ \\
& $0,36^{\mathrm{a}}$ & $4,2^{\mathrm{b}}$ & $10^{\mathrm{c}}$ & $0,089^{\mathrm{a}}$ \\
12 jam & $5,65 \pm$ & $82,1 \pm$ & $1,039 \pm$ & $0,246 \pm$ \\
& $0,33^{\mathrm{a}}$ & $8,7^{\mathrm{b}}$ & $20^{\mathrm{h}}$ & $0,098^{\mathrm{a}}$ \\
\hline
\end{tabular}

Keterangan: Angka yang sama menandakan tidak berbeda nyata pada taraf $\alpha 5 \%$

Setiap buah memiliki preferensi metode pengeringan yang berbeda. Jambu yang dikeringbekukan (freeze dried) mengalami perubahan warna yang minimal, akan tetapi pepaya akan berubah menjadi lebih pucat dengan teknik yang sama (Hawlader, 2006). Perubahan kadar polifenol, termasuk didalamnya pigmen warna, dalam pengolahan pasca panen dapat dipengaruhi oleh glikosilasi, asetilasi, dan metilasi pigmen (Provenzano et al., 2014). Polifenol oksidase (PPO) memiliki peran terbatas dalam menurunkan kadar antosianin oleh sebab gugus glikosida yang dimilikinya (Madrau et al., 2009). Degradasi komponen prosianidin dan antosianin dapat terjadi dikarenakan proses asidolisis (Devic et al., 2010). Selain antosianin, flavonoid yang umum ditemukan pada buah-buahan kaya polifenol adalah kuersetin dan kaemferol dari kelompok flavonol, serta katekin dari kelompok flavanol. Kelompok senyawa polifenol pada kulit buah 
bengalun secara total diukur berdasarkan ekuivalensi asam galat. Kadar total polifenol pada bengalun adalah $713 \pm 17$ hingga $1,112 \pm 8$ GAE/Kg (Tabel 4).

Degradasi komponen polifenol kulit buah bengalun diduga disebabkan oleh suhu dan aktivitas enzim PPO. Pada buah aprikot, enzim PPO masih mampu bertahan pada suhu pengeringan hingga $60^{\circ} \mathrm{C}$, sehingga polifenol seperti asam hidrosinamat dan katekin mengalami degradasi oksidatif (Madrau et al., 2009). Pengaruh suhu pengeringan terhadap total fenol pada suhu $40-60^{\circ} \mathrm{C}$ adalah berbeda nyata pada suhu $40^{\circ} \mathrm{C}$ bila dibandingkan dengan total fenol pada pengeringan kulit buah bengalun pada suhu 50 dan $60^{\circ} \mathrm{C}$. Diduga, enzim PPO yang ada pada kulit buah bengalun kurang mampu bertahan pada suhu $50^{\circ} \mathrm{C}$ ke atas. Pengaruh waktu pengeringan terhadap total fenol pada waktu 10 jam adalah berbeda nyata bila dibandingkan dengan total fenol pada pengeringan kulit buah bengalun pada waktu pengeringan 8 dan 12 jam (Tabel 3). Variasi standar deviasi hasil pengukuran yang tinggi menyebabkan tidak terdapat perbedaan yang nyata untuk total fenol kulit buah bengalun pada waktu pengeringan 8 dan 12 jam. Kecepatan degradasi polifenol, diukur dengan standar prosianidin, katekin, dan asam hidrosinamat, ditentukan dari dua faktor yaitu suhu dan waktu. Dibanding dengan faktor waktu, suhu pengeringan merupakan faktor utama yang mempengaruhi degradasi polifenol kulit buah bengalun. Hasil ini serupa dengan pengeringan apel (Devic et al., 2010).

\section{Antioksidan kulit buah bengalun}

Nilai $\mathrm{IC}_{50}$ aktivitas antioksidan terhadap $\mathrm{DPPH}$ dari kulit buah bengalun hasil pengeringan terbaik adalah 252,83 $\pm 1,38$ (Tabel 5). Menurut Shekhar et al. (2014), $I C_{50}$ merupakan konsentrasi larutan substrat atau sampel yang mampu mereduksi aktivitas DPPH sebesar $50 \%$, dimana semakin kecil nilai $I_{50}$ berarti semakin tinggi aktivitas antioksidan. Ekstrak bunga rosela dengan pelarut etanol 95\% memiliki nilai $I_{50}$ terhadap DPPH sebesar 1051,72 $\pm 184,20$ ppm (Yang et al., 2012).

Tabel 5. Perhitungan $\mathrm{IC}_{50}$ antioksidan metode DPPH ekstrak kulit buah bengalun dengan pelarut etanol

\begin{tabular}{ccc}
\hline Persamaan & $\mathrm{r}$ & $\mathrm{IC}_{50}(\mathrm{ppm})$ \\
\hline $\mathrm{y}=0,1199 \mathrm{x}+19,818$ & 0,993 & 251,73 \\
$\mathrm{y}=0,1195 \mathrm{x}+19,941$ & 0,993 & 251,54 \\
$\mathrm{y}=0,1201 \mathrm{x}+19,482$ & 0,991 & 254,11 \\
$\mathrm{y}=0,1201 \mathrm{x}+19,503$ & 0,992 & 253,93 \\
\hline \multicolumn{2}{c}{$\mathrm{IC}_{50}(\mathrm{ppm})$ rata-rata } & $252,83 \pm 1,38$ \\
\hline
\end{tabular}

Penggunaan pelarut berbeda dapat meningkatkan $\mathrm{IC}_{50}$, dimana ekstrak metanolik dari kulit buah manggis memiliki nilai $\mathrm{IC}_{50}$ terhadap DPPH sebesar
54,95 ppm (Dungir et al., 2012). Diketahui bahwa hubungan antara total fenolik dengan kemampuan pengikatan DPPH adalah kuat $(r=0,0997)$ terutama diidentifikasikan berasal dari keberadaan kuersetin dan kaemferol (Genovese et al., 2008).

\section{Kapasitas antibakteri kulit buah bengalun}

Beberapa tanaman dari keluarga Sapindaceae memiliki aktivitas antibakteria dan antifungi, utamanya dari akar, kulit batang, dan daun (De Lima et al., 2006). Ekstrak n-heksana dari pucuk Cardiospermum halicacabum, dalam keluarga Sapindaceae, memiliki nilai penghambatan minimum (MIC) 500 $\mu \mathrm{g} / \mathrm{mL}$ terhadap S. aureus (Maregesia et al., 2008). Ekstrak etanolik biji buah Paullinia cupana, juga dari keluarga Sapindaceae, memiliki MIC terhadap $E$. coli sebesar $32 \mu \mathrm{g} / \mathrm{mL}$ (Basile et al., 2005). Daya antimikroba yang lemah dapat diobservasi dari ekstrak etanol dan air kulit buah bengalun pada ketiga konsentrasi yang digunakan. Zona penghambatan pada konsentrasi ekstrak etanol tertinggi adalah 2,05 $\pm 0,5 \mathrm{~mm}(22,5 \%$ kontrol positif) terhadap E. coli dan 1,89 $\pm 0,02 \mathrm{~mm}(18,9 \%$ kontrol positif) terhadap $S$. aureus. Ekstrak n-heksana dari kulit buah bengalun tidak menunjukkan adanya aktivitas antimikroba pada konsentrasi yang diujikan (Tabel 6).

Tabel 6. Kapasitas antibakteri ekstrak kulit buah bengalun dengan berbagai pelarut terhadap bakteri uji $S$. aureus dan $E$. coli

\begin{tabular}{cccccc}
\hline \multirow{3}{*}{ Pelarut } & \multirow{2}{*}{ Bakteri } & \multicolumn{4}{c}{ Diameter Zona Hambatan $(\mathrm{mm})$} \\
\cline { 3 - 6 } & Uji & 0,5 & 1,0 & 1,5 & Tetrasiklin \\
& & $\mathrm{mg}$ & $\mathrm{mg}$ & $\mathrm{mg}$ & $0,5 \mathrm{mg}$ \\
\hline Etanol & E. coli & $1,26 \pm$ & $1,58 \pm$ & $2,05 \pm$ & $9,00 \pm$ \\
& & 0,01 & 0,07 & 0,07 & 0,00 \\
& $\mathrm{~S}$. & $1,11 \pm$ & $1,08 \pm$ & $1,89 \pm$ & $10,03 \pm$ \\
$\mathrm{N}-$ & aureus & 0,13 & 0,06 & 0,02 & 0,04 \\
heksana & E. coli & $0,00 \pm$ & $0,00 \pm$ & $0,00 \pm$ & $9,03 \pm$ \\
& & 0,00 & 0,00 & 0,00 & 0,04 \\
& S. & $0,00 \pm$ & $0,00 \pm$ & $0,00 \pm$ & $9,94 \pm$ \\
Akuades & aureus & 0,00 & 0,00 & 0,00 & 0,08 \\
& E. coli & $0,88 \pm$ & $0,95 \pm$ & $0,99 \pm$ & $9,00 \pm$ \\
& & 0,04 & 0,07 & 0,22 & 0,01 \\
& S. & $0,80 \pm$ & $0,81 \pm$ & $0,90 \pm$ & $10,01 \pm$ \\
& aureus & 0,07 & 0,06 & 0,01 & 0,01 \\
\hline
\end{tabular}

\section{KESIMPULAN}

Perlakuan suhu dan lama pengeringan berpengaruh nyata terhadap beberapa parameter yang diujikan, meliputi kadar air, vitamin $\mathrm{C}$, dan total fenol. Bubuk kulit buah bengalun memiliki kadar air berkisar 5,62 sampai dengan $7,68 \%$, vitamin $\mathrm{C}$ $55,7 \pm 11,5$ s.d. $85,6 \pm 2,5 \mathrm{mg} / \mathrm{kg}$, total fenolik $713 \pm 17$ sampai dengan $1112 \pm 8 \mathrm{mg}$ GAE$/ \mathrm{kg}$, dan antosianin yang didekati dengan absorbansi warna merah $0,081 \pm 0,013$ sampai dengan 0,259 $\pm 0,060$. Kulit buah bengalun yang terbaik dihasilkan dari perlakuan pengeringan suhu $60^{\circ} \mathrm{C}$ dengan lama 
pengeringan 8 jam dengan total fenol sebesar $1,112 \pm 8 \mathrm{mg}$ GAE$/ \mathrm{kg}$ dan absorbansi warna merah sebesar 0,259 $\pm 0,060$. Nilai aktivitas antioksidan $\left(\mathrm{IC}_{50}\right)$ terhadap DPPH rata-rata dari produk dengan perlakukan tersebut adalah $252,83 \pm 1,38$ ppm. Dari hasil eksplorasi terhadap aktivitas antibakteri, ekstrak kulit buah bengalun dengan menggunakan pelarut etanol dan air menghasilkan penghambatan yang rendah bila dibandingkan dengan kontrol. Ekstrak kulit buah bengalun dari perlakukan terbaik memiliki diameter hambatan yang berbeda pada $S$. aureus dan $E$. coli terhadap variasi pelarut yang digunakan. Diameter hambatan terhadap E. coli dan $S$. aureus yang paling besar dihasilkan oleh ekstrak etanol $95 \%$ dengan konsentrasi $1,5 \mathrm{mg}$ dengan

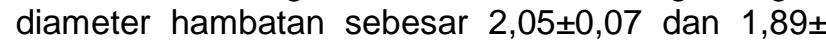
$0,02 \mathrm{~mm}$ atau 22,77 dan $18,84 \%$ dari masingmasing kontrol positif setiap bakteri uji. Ekstrak nheksana dari kulit buah bengalun tidak mampu menunjukkan adanya aktivitas antimikroba pada konsentrasi yang diujikan.

\section{UCAPAN TERIMA KASIH}

Ucapan terima kasih disampaikan penulis kepada Kemenristekdikti yang telah membiayai penelitian ini dalam skema hibah fundamental tahun 2015-2016 nomor kontrak 197/UN17.16/PG/2015. Data kapasitas antibakteri telah dipresentasikan dalam International Conference on Food, Agriculture, and Cullinary Tourism, Agustus 2015 di Samarinda.

\section{DAFTAR PUSTAKA}

[AOAC] Association of Official Analytical Chemists. 1984. AOAC Official Methods of Analysis. di dalam: Sudarmadji S, B Haryono, dan Suhardi. 2007. Analisa Bahan Makanan dan Pertanian. Hal: 1-172. Liberty Yogyakarta Bekerja Sama dengan Pusat Antar Universitas Pangan dan Gizi Universitas Gajah Mada. Yogyakarta.

Basile A, Ferrara L, Del Pezzo, M, Mele G, Sorbo S, Bassi P, Montesano D. 2005. Antibacterial and antioxidant activities of ethanol extract from Paullinia cupana Mart. J Ethnopharmacol 102: 32-36. DOI: 10.1016/j.jep.2005.05.038.

Basitah T. 2015. Extraction, characterization and application of natural dyes from the fresh rind of index colour 5 mangosteen (Garcinia mangostana L.). Int Scholarly Sci Res Innov 9: 871874.

Chinedum E, Kate E, Sonia C, Ironkwe A, Andrew I. 2015. Polyphenolic composition and antioxidant activities of 6 new turmeric (Curcuma Longa L.) accessions. Recent Pat Food Nutr Agric 7: 22-
7. DOI: $10.2174 / 2212798407666150401104$ 716.

Chotimah HENC, Krensnatita S, Miranda Y. 2013. Ethnobotanical study and nutrient content of local vegetables consumed in Central Kalimantan, Indonesia. Biodiversitas 14: 106-111. DOI: 10.13057/biodiv/d140209.

De Lima MRF, De Souza Luna J, Dos Santos AF, De Andrade MCC, ASant'Ana AEG, Genet J, Marquez B, Neuville L, Moreau N. 2006. Antibacterial activity of some Brazilian medicinal plants. J Ethnopharmacol 105: 137-147. DOI: 10.1016/j.jep.2005.10.026.

Devic E, Guyot S, Daudin J, Bonazzi C. 2010. Kinetics of polyphenol losses during soaking and drying of cider apples. Food Bioprocess Technol 3: 867-877. DOI: 10.1007/s11947-0100361-1.

Dungir SG, Katja DG, Kamu VS. 2012. Aktivitas antioksidan ekstrak fenolik dari kulit buah manggis (Garcinia mangostana L.). J Mipa Unsrat Online 1: 11-15.

Genovese MI, Da Silva Pinto M, De Souza schmidt goncalves ae, Lajolo FM. 2008. bioactive compounds and antioxidant capacity of exotic fruits and commercial frozen pulps from Brazil. Food Sci Tech Int 14: 207-214. DOI: 10.1177/108 2013208092151.

Gokilamani N, Muthukumarasamy N, Thambidurai M, Ranjitha A, Velauthapillai D. 2013. Utilization of natural anthocyanin pigments as photosensitizers for dye-sensitized solar cells. J SolGel Sci Technol 66: 212-219. DOI 10.1007/ s10971-013-2994-9.

Harun N, Evi R, Meiyanni A. 2011. Karakteristik teh herbal rambut jagung (Zea mays) dengan perlakuan lama pelayuan dan lama pengeringan. J Sagu 10: 16-21.

Hawlader MNA, Perera CO, Tian M, Yeo KL. 2006. Drying of guava and papaya: impact of different drying methods. Dry Technol 24: 77-87. DOI: 10.1080/07373930500538725.

Kusumaningrum R, Agus S, Siti HRJ. 2013. Karakteristik dan mutu teh bunga lotus (Nelumbo nucifera). J Teknol Hasil Perikanan 2: 9-21.

Lim TK. 2013. Lepisanthes alata: Edible Medicinal and Non-Medicinal Plants 6 (Fruits): 39-41. Springer Science and Business Media, Netherlands. DOI: 10.1007/978-94-007-5628-1_7.

Lopez J, Uribe E, Vega-Gálvez A, Miranda M, Vergara J, Gonzalez E, Di Scala K. 2010. Effect of air temperature on drying kinetics, vitamin C, antioxidant activity, total phenolic content, nonenzymatic browning and firmness of blueberries variety o'neil. Food Bioprocess Technol 3: 772777. DOI: 10.1007/s11947-009-0306-8.

Luzia DMM, Jorge N. 2011. Study of antioxidant activity of non-conventional Brazilian fruits. J 
Food Sci Technol 51: 1167-1172. DOI: 10.100 7/s13197-011-0603-x.

Madrau MA, Piscopo A, Sanguinetti AM, del Caro A, Poiana M, Romeo FV, Piga A. 2009. Effect of drying temperature on polyphenolic content and antioxidant activity of apricots. Eur Food Res Technol 228: 441-448. DOI: 10.1007/s00217008-0951-6.

Maregesia SM, Pieters L, Ngassapa OD, Apers S, Vingerhoets $R$, Cos $P$, Vanden Berghe DA, Vlietinck AJ. 2008. Screening of some tanzanian medicinal plants from bunda district for antibacterial, antifungal and antiviral activities. $\mathrm{J}$ Ethnopharmacol 119: 58-66. DOI: 10.1016/j. jep.2008.05.033.

Marfil PHM, Santos EM, Telis VRN. 2008. Ascorbic acid degradation kinetics in tomatoes at different drying conditions. LWT-Food Sci Technol 41: 1642-1647. DOI: 10.1016/j.Iwt.2007.11.003.

Mirfat AHS, Umi KHZ. 2014. Proximate composition of Malaysian underutilised fruits. J Tropical Agric Food Sci 42: 63-71.

Mun'im A, Hanani E, Mandasari A. 2008. Pembuatan teh herbal campuran kelopak bunga rosella (Hibiscus sabdariffa) dan herba seledri (Apium graveolens). Majalah IImu Kefarmasian 5: 47-54. DOI: 10.7454/psr.v5i1. 3418.

Purnomo. 2013. Pemanfaatan Kulit Buah Naga Merah (Hylocereus polyrhizus) sebagai Teh Berkhasiat. [Skripsi]. Fakultas Pertanian. Universitas Riau, Riau.

Provenzano S, Spelt C, Hosokawa S, Nakamura N, Brugliera F, Demelis L, Geerke DP, Schubert A, Tanaka Y, Quattrocchio F, Koes R. 2014. Genetic control and evolution of anthocyanin methylation. Plant Physiol 165: 962-977. DOI: 10.1104/pp.113.234526.

Rahmadi A, Abdiah I, Sukarno MD, Purna NT. 2013. Karakteristik fisiokimia dan antibakteri virgin coconut oil hasil fermentasi bakteri asam laktat. J Teknol Industri Pangan 24: 151-156. DOI: 10.6066/jtip.2013.24.2.178.

Santos PHS, Silva MA. 2008. Retention of vitamin C in drying processes of fruits and vegetables - a review. Dry Technol 26: 1421-1437. DOI: 10.1080/07373930802458911.
Sepdahlia. 2013. Uji aktivitas antibakteri ekstrak etanol kulit buah langsat (Lansium domesticum Cor.) terhadap Shigella flexneri. J Mahasiswa PSPD FK Universitas Tanjungpura 3: 173. http://jurnal.untan.ac.id/index.php/jfk/article/view /3785 [22 April 2016].

Setyowati FM, Riswan S, Susiarti S. 2005. Etnobotani masyarakat dayak ngaju di daerah timpah kalimantan tengah. J Tek Ling P3LBPPT 6: 502-510.

Shekhar, TC, Anju G. 2014. Antioxidant activity by DPPH radical scavenging method of Ageratum conyzoides Linn. leaves. Am J Ethnomed 1: 244-249.

Simanjuntak L, Chairina S, Fatimah. 2014. Ekstraksi pigmen antosianin dari kulit naga merah (Hylocereus polyrhizus). J Teknik Kima 3: 2529.

Vega-Gálvez A, Lemus-Mondaca R, Tello-Ireland C, Miranda M, Yagnam F. 2009. Kinetic study of convective drying of blueberry variety o'neil (Vaccinium corymbosum). Chil J Agr Res 69: 171-178. DOI: $0.4067 /$ S0718-5839200900020 0006.

Wisitsak P, Nimkamnerd J, Thitipramote N, Saewan N, Chaiwut P, Pintathong P. 2012. Comparison of the Bioactive Compounds and Their Activities between Longan and Litchi Seeds Extracts. Proceeding. 1st Mae Fah Luang University International Conference, Thailand.

Yang L, Gou Y, Zhao T, Zhao J, Li F, Zhang B, Wu X. 2012. Antioxidant capacity of extracts from calyx fruits of roselle (Hibiscus sabdariffa L.). Afr J Biotechnol 11: 4063-4068. DOI: 10.5897/ AJB11.2227.

Yeo SC, Awang Noor AG, Lee PC. 2013. The estimation of economic benefits of urban trees using contingent valuation method in Tasik Perdana, Kuala Lumpur. Pertanika J Trop Agric Sci 36: 99-114.

Zhou L, Cao Z, Bi J, Yi J, Chen Q, Wu X, Zhou M. 2016. Degradation kinetics of total phenolic compounds, capsaicinoids and antioxidant activity in red pepper during hot air and infrared drying process. Int J Food Sci Technol 51: 1365-2621. DOI: 10.1111/ijfs. 13050. 